\title{
Central Lines Infection Incidence and Risk Factors in an Intensive Care Unit, a Retrospective Cohort Study
}

\author{
Carlos Eduardo Rodriguez Rodriguez MD ${ }^{1}$, Manzo Palacios Ervin $\mathrm{MD}^{2}$, Gilberto Ortiz Cantu \\ MD $^{1}$, Ana Prixila González Vargas MD ${ }^{1}$, Eduardo Vidrio Duarte MD $^{1}$, Pedro Leonardo \\ Villanueva Solórzano MD ${ }^{1}$, Alberto Robles Méndez Hernández MD¹, María Teresa Gil \\ Corona $^{3}$, Bernardo Gutierrez Muñoz MD ${ }^{1}$, José Eduardo Vallejo Ramirez MD $^{4}$, Luis Angel \\ Medina Andrade $\mathrm{MD}^{4 *}$ \\ ${ }^{1}$ General Surgery Service, Universidad La Salle, Hospital Angeles Metropolitano, Mexico City, Mexico \\ ${ }^{2}$ Critical Area Coordinator, Hospital Angeles Metropolitano, Mexico City, Mexico \\ ${ }^{3}$ Cateter Control Department, Hospital Angeles Metropolitano, Mexico City, Mexico \\ ${ }^{4}$ General Surgery Service, Hospital General de Zona \#30, IMSS, Mexico City, Mexico
}

*Corresponding Author: Luis Angel Medina Andrade, General Surgery Service, Hospital General de Zona \#30, IMSS, Mexico City, Mexico, E-mail: buismedina_5@hotmail.com

\begin{abstract}
Background: The central lines are fundamental for the intra-hospital management of many patients, especially critical ones, but the complications associated with those devices like infection could increase the morbidity and mortality of patients. In this study we figure the factors associated with infection in a private hospital.
\end{abstract}

Material and Methods: We conduct a retrospective study including 710 patients with central venous catheters in the period from 2014 to 2017. General data and variables like age, diagnosis, days of catheter use, site of insertion, number of punction and others were registered and analyzed.

Results: From the total analyzed patients only 19 present central venous line associated infection (.026\%), from the analyzed factors only the number of catheter lumen and the days with catheter were significantly associated with infection, the most frequent microorganism was the Staphylococcus epidemidis as mentioned in the literature. Factors like number of punction during installation, site of placement, service of installation or diagnosis did not show significant results.

Conclusion: The incidence of infection in the hospital was very low compared with worldwide literature, and the risk factors associated with this are similar to previous described including multiple lumens and days with catheter, some of them have been described but not significant in our population, maybe secondary to sample size or hospital bias. A prospective study would be useful for morespecific results.

Keywords: Central Venous Line, Central Catheter Infection, Hospitalary Infection, Catheter associated sepsis.

\section{INTRODUCTION}

The central lines are fundamental for the intrahospital management of many patients, especially in the intensive care unit, for their use for drugs infusion, liquids, blood products; hemodialysis, blood samples or hemodynamic monitoring [1].

The central lines placement are associated with infectious, mechanic and thrombotic complications [2,3]. The associated infections represent serious consequences in morbidity, mortality and hospitalization cost for the patients and their families [4,5].

The objective of this study was to clarify the incidence, risk factors and more frequents pathogens for bacteremia and secondary infections associated with central lines in the medical or surgical patients in the Hospital Angeles Metropolitano in México between 2014 and 2017.

\section{Patients And Methods}

Study design: This was a retrospective cohort study developed in the Hospital Angeles 
Metropolitano (Intensive Care Unit, Intermediate Care Unit, Hospitalization), with 160 beds, between 2014 and 2017. A total of 2723 catheters were placed, and all were included in the analysis.

The sociodemographic data like age, sex, and other variables like diagnosis, related diseases, type of catheter, number of punctures during the placement and other were registered and analyzed.

The inclusion criteria were: age between 17-90 years-old, without active infection process at another level, with SIRS and bacteremia criteria according to IDSA consensus:

\subsection{BI (Bloodstream Infection) Confirmed by Laboratory by One of the Following Criteria}

One or more blood culture allowing the isolation of a pathogenic microorganism not related to another site of infection. Also, with two or more of the signs, symptoms or laboratory data: fever, hypothermia, hypotension, tachycardia, tachypnea, PCO2 <32 mmHg, leukocytes > $12.000 / \mathrm{ml}$, leukopenia <4.000 leukocytes $/ \mathrm{ml}$, Immature neutrophils in blood $>10 \%$.

Patient with two or more blood cultures from different punction sites, the same day or in consecutive days, with the same microorganism; and with two or more of the next signs, symptoms or laboratory data: fever, hypothermia, hypotension, tachycardia, tachypnea, PCO2 <32 mmHg, leukocytes > $12.000 / \mathrm{ml}$, leukopenia <4.000 leukocytes $/ \mathrm{ml}$, Immature neutrophils in blood $>10 \%$.

\subsubsection{Commentaries}

This diagnosis was determined with less than 24 hours of hospital stay if: a) background of invasive procedures b) background of intravascular therapy.

An IBI associated with health care must be considered in patients that fulfill the mentioned clinical and microbiologic criteria until 72 hours after discharge, or in who was not possible to identify another site of infection.

ITS related with catheter when the catheter was placed $48 \mathrm{~h}$ previous to the beginning of symptoms, and the presence of one of the next criteria: blood culture from catheter and peripheral punction, a positivity time of 2 hours (first the central and the peripheral after), or 103 CFU in qualitative blood culture. Also, with two or more of the next signs, symptoms or laboratory data: fever, hypothermia, hypotension, tachycardia, tachypnea, $\mathrm{PCO} 2<32$ $\mathrm{mmHg}$, leukocytes $>12.000 / \mathrm{ml}$, leukopenia $<4.000$ leukocytes $/ \mathrm{ml}$, Immature neutrophils in blood $>10 \%$.

Patient with one or more blood cultures that allow isolation of a pathogenic microorganism not related with another site of infection; and the same microorganism isolated in the catheter tip (Maki technique) with $15 \mathrm{CFU}$ by plate in case of semi quantitative cultures or $102 \mathrm{CFU}$ in quantitative cultures and with one or more of the next signs, symptoms or laboratory data: fever, hypothermia, hypotension, tachycardia, tachypnea, PCO2 <32 mmHg, leukocytes > $12.000 / \mathrm{ml}$, leukopenia <4.000 leukocytes $/ \mathrm{ml}$, Immature neutrophils in blood $>10 \%$.

\subsection{Exclusion Criteria: Files with Incomplete Data}

\subsubsection{Statistics}

Descriptive statistics and analysis with SPSS $^{\circledR}$ v.14., using one variable analysis and determining incidences and frequencies. Finally, with the obtained results a proposal of actions to diminish these problems would be suggested.

The presented study was a retrospective research work, descriptive and longitudinal, developed by files review of clinical data, in surgical and medical patients, of the Hospital Angeles Metropolitano in Mexico City, from 2014 to 2017.

Initially, a recollection data instrument was designed, with sociodemographic data like age, sex, other variables like diagnosis and related diseases are registered. The objective is to identify the incidence of central lines associated infections and the associated microorganism, with posterior analysis of risk factors.

\subsection{Statistical Analysis}

The database was performed, and the statistical program SPSS version 23.0 for Mac IOS 10.6 was used to perform statistical data analysis. Complications, risk factors, and general characteristics were registered and compared between the groups using $\mathrm{X}^{2}$ test, with $\mathrm{p}<.05$ indicating a significant correlation. A multivariate analysis was performed for the independent variables and the possible association with complications, all of this with a $95 \%$ interval confidence. 
Central Lines Infection Incidence and Risk Factors in an Intensive Care Unit, a Retrospective Cohort Study

\section{RESULTS}

An analysis of the clinical files of the infection control department was realized, from the catheter management division, from 2014 to 2017, and 2723 files were reviewed. A total of 710 patients were included.

\subsection{Catheter Characteristics}

The medicated catheter (chlorhexidine) 7 Fr, placed without ultrasonographic guidance: 288 male patients $(40.6 \%)$, and 422 female patients $(59.4 \%)$. The global average age was 48.78 years old, with ages from 0 to 95 years.

\subsubsection{Type of Patient}

Surgical patients: 221 patients in total $(31.22 \%)$; Non-surgical patients: 489 (68.93\%).

\subsubsection{Reason for Installation}

Necessity of a central access for solutions and intravenous drugs: 409 (57.6\%); Chemotherapy administration: 177 (24.9\%); Total parenteral nutrition: 5 (0.7\%); solutions, intravenous drugs and NPT: 78 (11\%); hemodialysis 9 (1.3\%) other: Difficulty to obtain a peripheral Access in critic patient: $32(4.5 \%)$.

Table1. Reason for central venous line installation

\begin{tabular}{|l|l|l|}
\hline $\begin{array}{l}\text { Reason for } \\
\text { installation }\end{array}$ & Frequency & Percentage \\
\hline Critical patients & 32 & 4.5 \\
\hline Solutions and drugs & 409 & 57.6 \\
\hline $\begin{array}{l}\text { Total parenteral } \\
\text { nutrition }\end{array}$ & 5 & .7 \\
\hline $\begin{array}{l}\text { Solutions and drugs, } \\
\text { total parenteral } \\
\text { nutrition. }\end{array}$ & 78 & 11.0 \\
\hline Hemodialysis & 9 & 1.3 \\
\hline Chemotherapy & 177 & 24.9 \\
\hline Total & 710 & 100.0 \\
\hline
\end{tabular}

\subsubsection{Site of Insertion}

Right subclavian in $426(65.84 \%)$; left subclavian 109(16.84\%); Total: 535 (82.68\%), right yugular 91(14.06\%), left yugular 18 $(2.78 \%)$; Total: 109 (16.84\%)and other (braquial, femoral, umbilical) $0.46 \%$.

\subsubsection{Number of Punctures During Installation}

One punction (548) 84.69\%; two (51) $7.88 \%$, three (3) $0.46 \%$, more than three (26) $4.01 \%$.

\subsection{Service Performing Installation}

Operating Room; 328(43.4\%), Critical areas (Intensive care unit and coronary unit):193 (27.2\%), Emergency room: 40 (5.6\%), others (Hospitalization, catheters clinic: 169(23.8\%).
Table2. Service performing installation

\begin{tabular}{|l|l|l|}
\hline \multicolumn{3}{|c|}{ Service of installation } \\
\hline Service of installation & Frequency & Percentage \\
\hline Operating room & 283 & 39.9 \\
\hline $\begin{array}{l}\text { External } \\
\text { operating room }\end{array}$ & 25 & 3.5 \\
\hline ICU & 108 & 15.2 \\
\hline NICU & 44 & 6.2 \\
\hline Coronary unit & 41 & 5.8 \\
\hline Hospitalization & 39 & 5.5 \\
\hline Infections clinic & 123 & 17.3 \\
\hline Emergency service & 40 & 5.6 \\
\hline Intermediate therapy & 7 & 1.0 \\
\hline Total & 710 & 100.0 \\
\hline
\end{tabular}

Number of lumens: One lumen: 261 (36.8\%); two lumens: 98 (13.8\%); three lumens :(351) $49.4 \% .4 .8 \%$.

Table3. The number of catheter lumens and percentage

\begin{tabular}{|l|l|l|}
\hline \multicolumn{1}{|c|}{$\#$} & \multicolumn{1}{|c|}{ Frequency } & Percentage \\
\hline 1 & 261 & 36.8 \\
\hline 2 & 98 & 13.8 \\
\hline 3 & 351 & 49.4 \\
\hline Total & 710 & 100.0 \\
\hline
\end{tabular}

\subsection{Catheter Permanency}

One day: $134(18.85 \%)$; 2-5 days: 182 (25.65\%); 510 days: $153(21.63 \%)+10$ days:240 (33.84\%).

From the total of included catheters, only 19 of the $710(2.7 \%)$ develop symptoms of infection; the others were asymptomatic.

From the isolated microorganisms in the studied catheters and with infectious characteristics, the Staphylococcus epidermidis was the more frequent of the Gram (+), and the next was Klebsiella pneumoniae and Serratia marscesces.

In the analysis of risk factors for infection, the sex did not have any significant relation, with a $p=0.277$. The use of parenteral nutrition did not present relation with catheter infection, with a $\mathrm{p}=0.486$. The sex was not related to the incidence of infection, with a $\mathrm{p}=0.567$. The presence of infection was not influenced by the performance of any surgery, with a $\mathrm{p}=0.695$. The other analyzed risk factors like diagnosis attempts for placement, co morbidities, number of lumens, service of placement,

A factor that presents a significant relation with the incidence of infection was the age of the patients, with a median age of 34.88 years in the infected cases vs. 49.26 years in the not infected cases, with a difference of 14.34 years, and a $\mathrm{p}=.007$. This risk factor could be explained by the newborns' cases in the study, with critical 
health and immature immune system, favoring the infection.

The number of lumens presented a significant correlation with the incidence of infection, with the catheters of three lumens developing more infections with a $\mathrm{p}=0.027$ (Table 4).

Table4. The significance of the number of lumens in central lines vs. infection

\begin{tabular}{|c|c|c|c|}
\hline \multicolumn{4}{|c|}{$\begin{array}{l}\text { Pearson chi-square test number of central line } \\
\text { lumen vs infection. }\end{array}$} \\
\hline & Value & gl & $\begin{array}{c}\text { Asymptotic } \\
\text { Significance } \\
\text { (bilateral) }\end{array}$ \\
\hline $\begin{array}{l}\text { Pearson Chi } \\
\text { square test }\end{array}$ & $7.246^{\mathrm{a}}$ & 2 & .027 \\
\hline $\begin{array}{l}\text { Reason for } \\
\text { credibility }\end{array}$ & 8.150 & 2 & .017 \\
\hline $\begin{array}{l}\text { Lineal } \\
\text { association }\end{array}$ & 7.162 & 1 & .007 \\
\hline $\mathrm{N}$ & 710 & & \\
\hline
\end{tabular}

Other risk factors associated in a significant manner with infection were the days of the catheter, with a $\mathrm{p}=0.000$ after Mann-Whitney $\mathrm{U}$ test (and 6).

Table5. The number of days with catheter range

\begin{tabular}{|l|l|r|r|r|}
\hline & Infection & N & Range & $\begin{array}{c}\text { Sum of } \\
\text { ranges }\end{array}$ \\
\hline \multirow{2}{*}{$\begin{array}{l}\text { Days of } \\
\text { catheter }\end{array}$} & Non-infected & 691 & 348.70 & 240953.50 \\
\cline { 2 - 5 } & Infected & 19 & 602.71 & 11451.50 \\
\cline { 2 - 5 } & Total & 710 & & \\
\hline
\end{tabular}

Table6. Mann-Whitney U test of days with catheter vs. infection

\begin{tabular}{|l|l|}
\hline & Days with catheter \\
\hline Mann-Whitney U test & 1867.500 \\
\hline W of Wilcoxon & 240953.500 \\
\hline$Z$ & -5.444 \\
\hline Asymptotic Sig. (bilateral) & .000 \\
\hline
\end{tabular}

\section{DISCUSSION}

The infections of the central venous catheter increase the morbidity, hospital stay and total cost of health care. Some risk factors for infections have been identified, like male sex, emergency surgery, and catheter use for more than 15 days. The frequently reported microorganism include staphylococcus negative coagulase, with the Staphylococcus aureus as the most frequent, and in our study, a Staphylococcus was the more frequent too [4]. Concerning days of catheter placement, the incidence of infection increases significantly according to the days since placement like the literature refers. The other factor identified in our study that increases the incidence of infection is the number of lumens.
We can see the infection-related catheter infection symptoms and signs in the insertion site or the catheter path. Alternatively, the clinical picture could be systemic and manifested with complications secondary to bacteremia like fever, the more frequent symptom in our study [1]. The catheterassociated sepsis is a critical point to the patient prognosis and considered as a marker for the health care quality [6]. The extra luminal microorganism influences the risk of blood infection related to the catheter in the insertion site [7].

In the United States of America, the annual cases of catheter-associated sepsis are 11000 in 2010 and 14400 in 4 Europe countries (France, Germany, Italy and United Kingdom) with associated annual health care cost between 35,9 and $€ 163,9$ millions [9-11]. (11) The catheterassociated sepsis continues as an essential problem for the patients of low, medium and high income [12].

The catheter line access bloodstream infection (CLABSI) is a substantial threat for the hospitalized patients, with an incidence of about 4.4 CLABSI for each 100 inserted devices [13].

The incidence of bacteremia associated with an intravascular catheter has diminished in the last decades, in the United States from 3.64 to 1.53 for every 1000 days of use between 2001 to 2009 [14]. However, the incidence in Latin America is significantly superior, with 6.8 cases for every 1000 days/catheter [15].

The relative risk of bacteremia associated with the intravascular catheter and total parenteral nutrition is 2.6 times higher than the one not associated with parenteral nutrition [16], and the associated mortality is variable from 13.9 to $18.6 \%$ [17].

The central venous catheters can produce an infection by three routes, intraluminal, extraluminal and bloodstream. The incidence in patients submitted to gastrointestinal surgical procedures is 5.6 for every 1000 days/catheter $[18,1]$.

In our study, we observed that the Staphylococcus epidermidis was the most frequent Gram (+) microorganism isolated, followed by Serratia and Klebsiella.

The subclavian vein catheterization has less risk of infection but higher risk of pneumothorax compared with the jugular or femoral locations, 
in our study may be secondary to our sample size the incidence of infection in the subclavian site or other sites were not significantly higher [3].

In a systematic review and meta-analysis comparing the risk of CLABSI between peripherally inserted central catheters infection and central venous catheter, the risk was ten times higher of CLABSI in the hospitalized patients $(5,2 \%)$ compared with the ambulatory patients that receive a peripheral catheter $(0,5 \%)$. Although, the hospitalized patients that underwent a peripherally inserted central catheter had similar CLABSI incidence compared with the CVC [20].

Some measures to prevent CLABSI are sterile barriers, site of insertion disinfection, and avoidance of femoral insertion site [21-23]. Since 1980, the impregnation of the catheter with antiseptics and antibiotics have been performed [24]; some of them include chlorhexidine-silver sulfadiazine (CSS) and minocycline-rifampicin (MNR), both the more studied to the date. We used other compounds like silver, platinum, carbon or heparin as impregnated materials for CVC [25]. Other manuscripts mention that the antibiotic impregnation in the CVC inhibit the bacteria colonization in the catheter surface and avoid their diffusion in the blood stream. Of those techniques, the most effective is the impregnation with minocycline-rifampicin [26].

The biofilm generation by the bacteria's produces the late infection of the bloodstream. This biofilm confers to the bacteria's the capacity to avoid the effect of antibiotics and the immune system, with the subsequent travel in the bloodstream [27].

We can see the symptoms and signs of infection in the site of insertion or the path of a dispositive with tunnels. Alternatively, the signs could be systemic or complicated by bacteremia [6].

The infection, thrombosis and mechanic complications are related to the site of the catheter insertion site. The extra luminal bacteria colonization is responsible for the risk of infection in the bloodstream, and the location with less risk of infection is the subclavian [28].

The use of a covered antibiotic catheter reduces the bloodstream infections in a significant way $[3,18]$. The catheter covered with chlorine and silver sulfadiazine only diminish the risk of infection in the first 48 hours after installation [29]. In the procedures of placement, there is an element frequently using, the heparin that according to some studies promote the formation of biofilm by Staphylococcus aureus [18].

The beginning of antibiotic therapy in patients with central venous catheter-related infection must be only in the ones with symptoms of colonization, severe disease or APACHE $>5$. There exist better results when the diagnosis is early diagnosis and treatment is associated with better results.

\section{CONCLUSIONS}

The presented study analyses risk factors for central venous lines infection in a private hospital in Mexico City, with all the international guidelines recommendations for catheter placement and management, with a low incidence of infection and by the more frequent bacteria species as reported in the international literature, with some of the previously reported factors increasing the incidence of infection. Some of the classical risk factors for infection were not significant in our study may be for the type of pathologies treated, and the number of patients included that could increase the risk of bias. More prospective studies are needed to determine the real differences in risk factors for infection of central venous lines in our hospital compared to the literature.

\section{REFERENCES}

[1] Bell T, O'Grady NP. Prevention of Central Line-Associated Bloodstream Infections. Infectious Disease Clinics of North America. septiembre de 2017;31(3):551-9.

[2] Arvaniti K, Lathyris D, Blot S, ApostolidouKiouti F, Koulenti D, Haidich A-B. Cumulative Evidence of Randomized Controlled and Observational Studies on Catheter-Related Infection Risk of Central Venous Catheter Insertion Site in ICU Patients: A Pairwise and Network Meta-Analysis. Critical Care Medicine. abril de 2017;45(4):e437-48.

[3] Parienti J-J, Mongardon N, Mégarbane B, Mira J-P, Kalfon P, Gros A, et al. Intravascular Complications of Central Venous Catheterization by Insertion Site. New England Journal of Medicine. el 24 de Septiembre de 2015;373(13):1220-9.

[4] Ziegler MJ, Pellegrini DC, Safdar N. Attributable mortality of central line-associated bloodstream infection: systematic review and meta-analysis. Infection. febrero de 2015;43(1):29-36. 
[5] Purba AKR, Setiawan D, Bathoorn E, Postma MJ, Dik J-WH, Friedrich AW. Prevention of Surgical Site Infections: A Systematic Review of Cost Analyses in the Use of Prophylactic Antibiotics. Frontiers in Pharmacology [Internet]. el 18 de julio de 2018 [citado el 31 de Agosto de 2018];9. Disponible en: https:// www.frontiersin.org/article/10.3389/fphar.2018 $.00776 /$ full

[6] Kornbau C, Lee K, Hughes G, Firstenberg M. Central line complications. International Journal of Critical Illness and Injury Science. 2015;5(3):170.

[7] Mermel LA. What Is The Predominant Source of Intravascular Catheter Infections? Clinical Infectious Diseases. el 15 de Enero de 2011;52(2):211-2.

[8] Mermel LA, Allon M, Bouza E, Craven DE, Flynn P, O'Grady NP, et al. Clinical Practice Guidelines for the Diagnosis and Management of Intravascular Catheter-Related Infection: 2009 Update by the Infectious Diseases Society of America. Clinical Infectious Diseases. julio de 2009;49(1):1-45.

[9] Chaftari A-M, Jordan M, Hachem R, Al Hamal Z, Jiang Y, Yousif A, et al. A practical clinical approach to the surveillance definition of central line-associated bloodstream infection in cancer patients with mucosal barrier injury. American Journal of Infection Control. agosto de 2016;44(8):931-4.

[10] FAQs: Bloodstream Infection (BSI) Events | NHSN | CDC [Internet]. 2017 [citado el 4 de Septiembre de 2018]. Disponible en: https://www.cdc.gov/nhsn/faqs/faq-bsi.html

[11] Saint S, Veenstra DL, Lipsky BA. The Clinical and Economic Consequences of Nosocomial Central Venous Catheter-Related Infection: Are Antimicrobial Catheters Useful? Infection Control \& Hospital Epidemiology. junio de 2000;21(06):375-80.

[12] Grau D, Clarivet B, Lotthé A, Bommart S, Parer S. Complications with peripherally inserted central catheters (PICCs) used in hospitalized patients and outpatients: a prospective cohort study. Antimicrobial Resistance \& Infection Control [Internet]. diciembre de 2017 [citado el 17 de julio de 2017];6(1). Disponible en: http://aricjournal. biomedcentral.com/articles/10.1186/s13756016-0161-0

[13] Maki DG, Kluger DM, Crnich CJ. The Risk of Bloodstream Infection in Adults With Different Intravascular Devices: A Systematic Review of 200 Published Prospective Studies. Mayo Clinic Proceedings. septiembre de 2006; 81(9):1159-71.

[14] Fagan RP, Edwards JR, Park BJ, Fridkin SK, Magill SS. Incidence trends in pathogen- specific central line-associated bloodstream infections in US intensive care units, 19902010. Infect Control Hosp Epidemiol. septiembre de 2013;34(9):893-9.

[15] Rosenthal VD, Bijie H, Maki DG, Mehta Y, Apisarnthanarak A, Medeiros EA, et al. International Nosocomial Infection Control Consortium (INICC) report, data summary of 36 countries, for 2004-2009. American Journal of Infection Control. junio de 2012;40(5):396407.

[16] Gavin NC, Button E, Keogh S, McMillan D, Rickard C. Does Parenteral Nutrition Increase the Risk of Catheter-Related Bloodstream Infection? A Systematic Literature Review. Journal of Parenteral and Enteral Nutrition. agosto de 2017;41(6):918-28.

[17] Saliba P, Hornero A, Cuervo G, Grau I, Jimenez E, García D, et al. Mortality risk factors among non-ICU patients with nosocomial vascular catheter-related bloodstream infections: a prospective cohort study. Journal of Hospital Infection. mayo de 2018;99(1):48-54.

[18] Wu S, Ren S, Zhao H, Jin H, Xv L, Qian S, et al. Risk factors for central venous catheterrelated bloodstream infections after gastrointestinal surgery. American Journal of Infection Control. mayo de 2017;45(5):549-50.

[19] Patil H, Ramteerthkar M, Patil V, Kulkarni R. Central venous catheter-related bloodstream infections in the intensive care unit. Indian Journal of Critical Care Medicine. 2011; 15(4): 213.

[20] Chopra V, O’Horo JC, Rogers MAM, Maki DG, Safdar N. The Risk of Bloodstream Infection Associated with Peripherally Inserted Central Catheters Compared with Central Venous Catheters in Adults: A Systematic Review and Meta-Analysis. Infection Control \& Hospital Epidemiology. septiembre de 2013;34(09):908-18.

[21] Hu KK, Lipsky BA, Veenstra DL, Saint S. Using maximal sterile barriers to prevent central venous catheter-related infection: a systematic evidence-based review 2 . American Journal of Infection Control. mayo de 2004;32(3):142-6.

[22] Gonzales M, Rocher I, Fortin É, Fontela P, Kaouache M, Tremblay C, et al. A survey of Preventive Measures Used and their Impact on Central Line-Associated Bloodstream Infections (CLABSI) in Intensive Care Units (SPIN-BACC). BMC Infectious Diseases [Internet]. diciembre de 2013 [citado el 10 de Septiembre de 2018];13(1). Disponibleen: http://bmcinfectdis.Biomedcentral. com/articles/10.118 6/14 71-2334-13-562. 
[23] Marsh N, Webster J, Mihala G, Rickard CM. Devices and dressings to secure peripheral venous catheters to prevent complications. Cochrane Wounds Group, editor. Cochrane Database of Systematic Reviews [Internet]. el 12 de Junio de 2015 [citado el 11 de Septiembre de 2018]; Disponible en: http://doi.wiley.com/ 10.1002 /858.CD011070.pub2.

[24] Perin DC, Erdmann AL, Higashi GDC, Sasso GTMD. Evidence-based measures to prevent central line-associated bloodstream infections: a systematic review. Revista Latino-Americana de Enfermagem [Internet]. 2016 [citado el 10 de Septiembre de 2018];24(0). Disponible en: http://www.scielo.br/scielo.php?script=sci_artte xt\&pid=S0104-11692016000100612\&lng=en\& tlng=en.

[25] Ling ML, Apisarnthanarak A, Jaggi N, Harrington G, Morikane K, Thu LTA, et al. APSIC guide for prevention of Central LineAssociated Bloodstream Infections (CLABSI). Antimicrobial Resistance \& Infection Control [Internet]. diciembre de 2016 [citado el 10 de Septiembre de 2018];5(1). Disponible en: http://aricjournal.biomedcentral.com/articles/10 .1186/s13756-016-0116-5.

[26] Chong HY, Lai NM, Apisarnthanarak A, Chaiyakunapruk N. Comparative Efficacy of Antimicrobial Central Venous Catheters in Reducing Catheter-Related Bloodstream Infections in Adults: Abridged Cochrane Systematic Review and Network Meta-
Analysis. Clinical Infectious Diseases. el 15 de mayo de 2017;64(suppl_2): S131-40.

[27] Mishra S, Horswill AR. Heparin Mimics Extracellular DNA in Binding to Cell SurfaceLocalized Proteins and Promoting Staphylococcus aureus Biofilm Formation. Fey PD, editor. sphere [Internet]. el 28 de Junio de 2017 [citado el 9 de Agosto de 2018];2(3). Disponible en: http://msphere.asm.org/_lookup/ doi/10.112 8/mSphere.00135-17.

[28] Safdar N, Maki DG. The pathogenesis of catheter-related bloodstream infection with noncuffed short-term central venous catheters. Intensive Care Medicine. el 1 de Enero de 2004;30(1):62-7.

[29] Lai NM, Chaiyakunapruk N, Lai NA, O'Riordan E, Pau WSC, Saint S. Catheter impregnation, coating or bonding for reducing central venous catheter-related infections in adults. En: The Cochrane Collaboration, editor. Cochrane Database of Systematic Reviews [Internet]. Chichester, UK: John Wiley \& Sons, Ltd; 2016 [citado el 17 de julio de 2017]. Disponible en: http://doi.wiley.com/ 10.1002/ 14651858.CD00 7878.pub3

[30] De Egea V, Guembe M, Rodríguez-Borlado A, Pérez-Granda MJ, Sánchez-Carrillo C, Bouza E. Should in-bacteremic patients with a colonized catheter receive antimicrobial therapy? International Journal of Infectious Diseases. septiembre de 2017;62:72-6.

Citation: Carlos Eduardo Rodriguez Rodriguez et al. Central Lines Infection Incidence and Risk Factors in an Intensive Care Unit, a Retrospective Cohort Study. ARC Journal of Surgery.2019; 5(1):20-26. doi:dx.doi.org /10.20431/2455-572X. 0501004.

Copyright: (c) 2019 Authors. This is an open-access article distributed under the terms of the Creative Commons Attribution License, which permits unrestricted use, distribution, and reproduction in any medium, provided the original author and source are credited. 